\title{
The Vitality of Humanimality: From the Perspective of Life Phenomenology
}

\author{
Dr. Stephen J. Smith, Professor, Faculty of Education, Associate Dean, Faculty of Health \\ Sciences, Simon Fraser University \\ Email:stephen_smith@sfu.ca
}

\section{Abstract}

While interactions with other animate beings seem mostly to serve our own human interests, there are, at times, fugitive glimpses, passing contacts, momentary motions, and fleeting feelings of vital connection with other life forms. Life phenomenology attempts to realize these relational, interactive and intercorporeal possibilities. It challenges the language game of presuming the muteness and bruteness of non-human creatures and, at best, of speaking for them. It critiques the capture of non-human species within the inhibiting ring of human functions and forms to reveal feelings and flows of interspecies commonality. It brings to expression the experiences of being moved to act and speak with others who do not share the human tongue. In part a critique of the logocentric, anthropocentric phenomenologies of intentionality, life phenomenology is more positively a means of coming to terms with the life-affirming kinetic, kinesthetic and affective dynamics of interspecies relationality. I take up the interrogation of this phenomenality, this humanimality, with the assistance of phenomenological scholarship that lends fuller credence to the experiences we have of moving in concert with other animate beings. In doing so, I aim to show the important insights that life phenomenology offers us in fostering not only greater appreciation of, responsivenss to and connection with other animals, but also in indicating the qualitative dynamics of relating with greater animate consciousness to one another of our own animal kind. 


\section{Introduction}

I recall a childhood growing up by the ocean and spending much time poking around tide pools in rocky outcrops separating the almost continuous chain of beaches around the Australian Coast (cf. Smith, 1992). My vivid memories are as a six, seven and eight-year-old who delighted in the molluscs, periwinkles, sea anemones, tiny crabs and other life forms that revealed themselves in these pools and that provided a slower dynamic of engagement than the blennies and gobies darting from cracks to crevices. The creature that delighted me most was the blue-ringed octopus. Only a few inches in length, and difficult to see when stationary due to its muddy complexion, this little octopus glowed in iridescent purple rings when touched. I was always careful not to hurt it when catching it by hand, cradling it in my palms, and caressing the softsuctioned legs and body in order to watch the pulsing light show.

A few years later I heard a radio report by a marine biologist claiming the blue-ringed octopus found in Queensland coastal waters to be one of the more venomous creatures in Australia. Its glowing rings were said to be a warning of an imminent, paralyzing bite. That report, however, did not jibe with the sense I had of this furtive, gentle creature. Yet now knowing the caution required, I felt it could no longer be handled, even with great care.

Knowledge of the potential danger created an irreparable divide. Nevertheless, what I retain from such memory of creaturely encounter is the conviction not so much that animal science is wide of the mark but that the biology and ethology of an externalized nature has yet to come to terms with the life affinities that even and especially a child can intuit. As human beings, we affirm life in ways that are distinctive of our species, just as all other animate beings affirm life in ways particular and peculiar to theirs. But biological consideration of forms and functions is different than phenomenological interrogation of feelings and flows. And it is in this latter regard for life and its inherent, immanent, affective vitality that the ontological line between humans and other animate beings starts to blur and where the phenomena of humanimality become evident. ${ }^{1}$

My intent in this paper is to press the case for the vitality of humanimality, not so much from treating manifest similarities in function and form between humans and other animals, but from the perspective of a life phenomenology which has more to do with feelings and flows of interspecies attunement. The case is presented initially through reference to the work of Maxine Sheets-Johnstone in which an articulation of the "kinetic-kinesthetic-affective dynamics" of animate consciousness provides a lexicon for the felt and fluid interplay we can experience between ourselves and other creatures. Sheets-Johnstone's descriptive accounts of "self movement" potentially disclose, through mimetic, "vitality affects," the resonances and attunements of our own human movements with those of other creaturely kinds (SheetsJohnstone, 1999/2011; 2009).

${ }^{1}$ Ted Toadvine (2007) notes in his essay on human exceptionalism that while we may recognize that it is scientifically incorrect to believe that mankind is the superior form of life on earth, and that we would be wise to see our place in relational terms, the great challenge is in allowing for a phenomenology of animal lifeworlds that also allows for a reconceptualization of 'human' that is neither in opposition nor reducible to 'animal' (pp. 39-41). The word 'humanimality' has gained some currency in this non-oppositional and non-reductive reconciliation of humans and other animal beings. 
But I want to extend Sheets-Johnstone's phenomenological explication of animate consciousness more evidently and critically in its vital register of humanimality. In doing so, I reset the question of humanimality in keeping with the enduring emphases on functions and forms that privilege certain human beings. Martin Heidegger's explication of the human-animal divide seems inescapable except for the intimations he provides of its potential dissolution. While constrained still by the functionalism and formalism of human preoccupations, Heidegger's later sense of going along with the animal opens up possible spaces and times for feeling at one with another essentially animate being. Sheets-Johnstone's keen insights about moving in concert with others thus gain phenomenological force as indicating the very momentto-moment flux of a primal affiliation as a we-ness that can well up in our intercorporeal exchanges.

I call upon Michel Henry's (2008) radical phenomenology of the auto-affectivity of life to show where the phenomenological divide between transcendental self-affectivity and ekstatic world intentionality is linguistically, though not corporeally, drawn. Henry's phenomenology of life, while scarcely mentioning animals at all, is especially provocative in consideration of how the immanent auto-affectivity of life flows into ecstatic, hetero-affective expressions of vitality. His "reversal of phenomenology" (Henry, 2015), taking auto-affectivity to be the pre-worldly impressionality of manifest life expressions, is especially helpful in addressing the question of what moves us to go along with and move in concert with others and what, in particular, can move us to become imbued with the animations of others that we experience as equally our own movement impressions. In this regard, Henry answers the most telling motivational question that Sheets-Johnstone takes from Edmund Husserl as the problematic of the "I can" and in such a way as to revitalize the humanimality to which we can aspire.

\section{A Question of Motivation}

Let me begin by confessing that I am most interested in the practicality of interspecies relations as afforded by training, riding and playing with horses (e.g., Smith, 2011; 2014a; 2015a; 2015b; $2017 \mathrm{a}$ in press). By the same token, I remain interested academically, professionally and pedagogically in teacher-and-student dynamics and the interactions that are possible in primary, secondary and higher education when we take our movements seriously (e.g., Smith, 1998; 2007; $2013 ; 2014 b)$. The particular question that continues to bubble up in these various endeavors has to do with the motivation inherent to the animation of pedagogical, andragogical and what we might call hippogogical relations. Doing good and making a positive difference are fine motivational aspirations, just as replication, projection, control, management and surveillance are questionable ones for children, youth, adults and horses alike. But how do such aspirations actually play out dynamically, interactively and in the moment? Indeed, the general ascription of domestication and at times, domination, to horse and human relations, like the ascriptions of schooling, teaching, leading, training and coaching, gloss over the moment-to-moment motives that are rooted in "the sheer experience of aliveness, the sheer nonverbal kinetic experience of ourselves and others as animate forms" (Sheets-Johnstone, 1999, p. 225).

Sheets-Johnstone (2009) pursues the phenomenological question of movement agency, which is to say, the fundamental question of motivation, through Edmund Husserl's "epistemological-ontological insight that 'I move' precedes 'I do' and 'I can'” (p. 249) to show 
that prior to attributions of subjectivity, personality and egoic agency, there is "primal animation and its spontaneously experienced existential reality" (p. 250).

One could, from a Buddhist as well as phenomenological perspective, specify simply "moving, moving," the inherently qualitative dynamics of " moving, moving"' being what is experientially present and all that is experientially present. (p. 259)

The increasingly "familiar dynamics" of movement that "undergird our "elusively flowing life", (she writes, while continuing to reference Husserl) and that are "most commonly synergies of meaningful movement" are said to be akin to "a sub-melodic presence" (p. 259, emphasis in original). ${ }^{2}$

All of which is particularly appealing, but what I am most interested in getting at phenomenologically and as a practice of living are the motivational dynamics of animate consciousness that constitute mimetic attunements between otherwise distinguishable and separable animate beings. These mimetic, melodic, rhythmic, affective dynamics are felt specifically as rushes, bursts, surges, swells, risings, undulations, waves and flows (Smith, 2007). They are felt in the first instance, not as generalized feelings, emotions and moods, but as "vitality affects" (Stern, 1983; 2002; 2004; 2010) that are indicative of not just the quality of movement but of the very manner in which one is moving conjointly, concurrently, in synchronization with others (Sheets-Johnstone, 1999, pp. 143-160, 256, 257.) I, too, want to pursue "movement that is a piece with the nature of life itself" (Sheets-Johnstone, 2014, p. 253). In doing so, I now pose the question of how and to what extent interspecies interactivity brings up life in attesting to and elaborating upon the primacy of the kinetic-kinesthetic-affective connectivity to which Sheets-Johnstone has persistently drawn our attention. She writes: "the moment I put an 'I' or an 'ownership' into the experience, I am perceiving the movement, not feeling its dynamics pure and simple" (Sheets-Johnstone, 2014, p. 259).

What may indeed be properly described as moving in concert with others in an everyday sense - and in an aesthetic sense as well, as in performing in an orchestral concert, an opera, a dance concert, or a theater play - rests on our pre-reflective awareness of the foundational qualitative dynamics of movement and their variational possibilities. (p. 260)

Sheets-Johnstone goes on to state, "because we perceive the kinetic qualitative dynamics of other persons [and, by implication, other creatures] and kinesthetically feel the qualitative dynamics of our own movement, we are able to move in concert with others" (p. 262). ${ }^{3}$

Where this thinking about how to move in concert with others and specifically with other animals is going will now be taken up in three further illustrations of humanimality that point to progressive registers of "vital contact" (Smith, 2014). ${ }^{4}$ The first, namely the killing of a wild lion, questions human exceptionalism as not just overt dominion over nature's creatures but also

\footnotetext{
${ }^{2}$ Here can be heard echoes of Jakob von Uexküll's (2010) melodic, compositional and symphonic accounts of animal umwelten (lifeworlds).

${ }^{3}$ I make the implication to other creatures because Sheets-Johnstone goes on to mention on the next page of this article instances of moving "in concert" that include "riding a horse" (p. 263).

${ }^{4} \mathrm{I}$ use the word humanimality to indicate three registers of appreciation, responsiveness and connection with other animate beings that move from distal awareness to proximal contact.
} 
in terms of claims to distinctively human properties that justify proprietorial rights over others. The second illustration shows that, with the capture of animals being very much a function of our human self-captivation, the public killing of a captive gorilla can become the occasion for discerning the dynamics of interspecies responsiveness. The third illustration presses the case for the vitality of humanimality by imagining interspecies relationships to involve moving with other beings in deeply resonant ways. This illustration is closer to home and is indicative of the practices of training, riding and playing with horses. In discussing these illustrations, I draw upon pertinent writings of Heidegger that have us realize our anthropocentric limitations, pay continuing attention to Sheets-Johnstone's work as providing necessary discernment of the practically motivated ways we can come to move well with others, and present Henryean life phenomenology in answer to the question of what fundamentally motivates us to move together and in concert with other creatures.

\section{If a Lion Could Talk}

There was much furor over the sport-trophy killing of Cecil the lion. From claims of Illuminati messages to witnessing tears from hosts of Late Night television, something of this death touched millions around the globe. Yet what can we say about Cecil being taken by a trophy hunter in terms of an animal's passing that has made his past-presence seen, felt and voiced in ways that appear so much more diversely animated than when he was physically, actually alive? What would this passing into vicariously lived experience better say than all the invective and hate hurled on the internet against the Minnesota dentist who hunted and killed Cecil, and that would be more about approaching, affecting and languaging animality, whether in the life form of lordly lions or even as plebeian, parasitic ticks, such that life is valued in the face of the singular life that was so grotesquely taken?

One answer involves an appeal to traditional ways of knowing others, and especially to ways of knowing those of another animal kind. Consider hunting for sustenance and survival and the relationship between human hunter and animal prey that "comes to be regarded not as a technical manipulation of the natural world but as a kind of interpersonal dialogue... wherein both human and animal persons are constituted with their particular identities and purposes" (Ingold, 2000, p. 49). The hunted animal is tracked though a reading of its life form, its territorial range, patterns of movement and distinctive modes of appearing. The hunter identifies with the prey animal, shape-shifting as it were, and becoming a part of the animal's world. Tracking life, as Gregory Cajete (1994) explains, is a sustenance practice as well a metaphor of how all animate forms are interconnected (pp. 55-58). In Western terms, we might say the hunter has the sensibility of an ethologist borne from a participatory consciousness of the animal's lifeworld. And yet, this answer falls short of creating a counter-narrative to the Cecil the Lion story since the relationship between hunter and prey in traditional societies remains asymmetrical (Oma, 2010, pp. 176-179); furthermore, we are hard pressed today to imagine the capture and killing of the apex predator of the African plains in such hunter-gatherer terms and as anything more than human enthrallment in killing for killing's sake.

Ludwig Wittgenstein (1953) famously stated: "If a lion could speak, we could not understand him" (p. 223). This statement is surely more about Wittgenstein's language games and the self-imposed limits of human reason than about, say, Cecil the actual lion and what millions of people heard, imagined, remembered, projected, intuited, transposed, translated, in 
sensing his passing. Of course, Cecil and all the other lions killed as 'trophies' in horrendous 'canned hunts' should not just be appreciated in death. Surely we can ask: What good can come of all this tragedy? Maybe we need to dethrone human reason or at least be "looking ahead to animal-life" (Heidegger, 2016, p. 64) and announcing the arrival of an animal sense that is not constrained by the humanistic, sense-making shades of reason that are based on ratio and the balancing of interests between humans and other animal beings.

Certainly this illustration of Cecil the lion points out the felt poverty of Heideggerian "world-poorness" attributed to animals that is premised on animal "captivation." Indeed, a continuing reference to Martin Heidegger's fundamental ontology of Dasein, the being-thereness of homosapiency, and the relative world poorness of other animals, weaves through the phenomenological rendering of humanimality with few notable exceptions (Calarco, 2008). Animals, for Heidegger in 1929-1930, were considered "poor in world" whereas humans were "world-forming" while rocks and stones remained "worldless."

The animal is poor in world...in respect of what is accessible to it, of whatever as an animal it can deal with, of whatever it can be affected by as an animal, of whatever it can relate to as a living being." (Heidegger, 1995, p. 193)

Elsewhere and throughout his writings, Heidegger elaborated on animal deficiencies with respect to not having speech but only communication, not having history since they can forget but cannot remember, not having a destiny since they do not die but only perish, not having hands that hold tools but only claws, talons, hooves and paws of brute powers, not being able to dwell but only to take up space, and with the lone credit being a back-handed compliment about the animal's incapacity for the calculative reason that has gotten human beings into so much trouble (Eldon, 2006). It is essentially the animal's "captivation" within the "disinhibiting ring" of its afforded senses and behaviors that defines its world poorness. As Heidegger (1995) states:

the animal surrounds itself with a disinhibiting ring which prescribes what can affect or occasion its behavior. Since this self-encirclement belongs to the animal, it always intrinsically bears its disinhibiting ring along with it and does so as long as it is alive. Or more precisely - the life of the animal is precisely the struggle [Ringen] to maintain this encircling ring or sphere within which a quite specifically articulated manifold of disinhibitions can arise. (p. 255)

Fundamentally, the animal is captivated in its disinhibiting ring because it has no access to "beings as such" but only "beings in themselves" (p. 279). It does not see itself as animal, as lion, gorilla or horse in the way that human beings see themselves as such, others as such, and events, objects, things as this, that or the other. Of such assumed captivation is constituted the abyssal distinction between animal beings and human beings that mutes the objections to the sport hunting of animals, and that renders suspect both anthropocentric oppositions to and anthropomorphic identifications with that killing. ${ }^{5}$

\footnotetext{
${ }^{5}$ Giorgio Agamben (2002), following Heidegger, attributes the divide between human beings and other animate life forms to the workings of the "anthropological machine" that either humanizes the animal or animalizes the human. Either way, we are but cogs in the machine.
} 
There is a 1953 essay, however, where Heidegger offers insights into humanimality that differ from the animal "world-poorness" and human exceptionalism that we take from the widely-referenced 1929-1930 lecture course on The Fundamental Concepts of Metaphysics. They are to be found in Heidegger's treatment of the "Blue Game" (or the "Blue Deer") in his reading of Georg Trakl's poetry (Heidegger, 1971) where he uses language that is suggestive of Daniel Stern's "vitality affects" to describe more than "going along with the animal" and, indeed, positing a "Blueness" and "Blue Twilight" where human wayfarers and animal companions can come to really be with one another. Heidegger (1971) wrote:

The blue game is an animal whose animality presumably does not consist in its animal nature, but in that thoughtfully recalling look for which the poet calls. This animality is still far away, and barely to be seen. The animality of the animal here intended vacillates in the indefinite. It has not yet been gathered up into its essential being. (p. 166)

The blueness of the wild deer that the traveler encounters is expressive of that twilight time when the deer and the traveler look beyond themselves in non-oppositional "gentleness" (p. 166). The animal's "countering glance" which "is sighted by the night's blueness" (p. 167) draws the wandering stranger into an expansive human nature. "This stranger unfolds human nature forward into the beginning of what is yet to be borne" (p. 175) as that which is revealed in the "animate blue" (p. 194, emphasis added).

This twilight blueness "names the slippage of the between, the blurring of just such oppositions as the wild and the civilized, for example, and the appeasement of the antagonisms that they establish" (Mitchell, 2011, p. 76). Yet ultimately this blueness still seems too coldly serving of human interests, easily conflating the "blue deer" and the "blue game." $\mathrm{How}$ is one to go along with Cecil the Lion gently into the twilight of the Southwest African savanna rather than stalking and tracking him down in the harsh humanistic light of phenomenological reason? How is an expansiveness humanness to be experienced with lions and other creatures without their capture even in the benevolent realm of human imagination?

\section{Animals in Captivity}

The second illustration is that of Harambe the Western Lowland Gorilla who was shot at the Cincinnati Zoo when a three-year-old climbed a retaining fence, crawled through bushes, and then fell some sixteen feet into the shallow moat surrounding the Gorilla compound. Video posted on the internet shows Harambe at first gently stroking the child and then dragging him forcefully through the water while the boy's mother and zoo visitors look on helplessly and in horror.

\footnotetext{
${ }^{6}$ Jacques Derrida (2008) criticized Heidegger and the Western philosophical tradition for continuing to conflate all animals and deny them, as a whole, attributes claimed self-servingly by humans. "I would like to have the plural of animals heard in the singular," he wrote (cited in Atherton and Calarco, 2004) "to envisage the existence of 'living creatures' whose plurality cannot be assembled within the single figure of an animality that is simply opposed to humanity" (p. 125).
} 
Again we have an example of captivation and of the anthropocentric framing of interests that offers no real ontological exit let alone any moral compass beyond human rights and utilitarianism. Taking a Deluezian perspective, Felice Cimatti (2016) contends that "the zoo is not properly a physical place but a cognitive and ontological device. The Zoo is the perfect manifestation of the logic of language and names" (p. 42). And yet, the video evidence of Harambe's actions just prior to his death affords some degree of access to the "kinetickinesthetic-affective dynamics" of interspecies relationality. I see in this evidence, and underneath the layers of interpretive-projective commentary and knee-jerk accusations of blame, a re-thinking of animal "world poorness" and critique of the "as such" capability denied to animals in spite of the anthropomorphic attributions of language, affect and cognition as relatively limited potentialities. The zoo captivation of Harambe inevitably obscures any interplay of humanimal capabilities; by the same token, it seems the public viewing of the sequence of interactions between Harambe and the child that lead up to Harambe's killing inspired considerable postural, gestural, expressive and complexioned identifications.

Noted primatologist Jane Goodall responded to this event with a letter to the Cincinatti Zoo administrators and then via an interview on the website of the "International Fund for Animal Welfare" (Downs, 2016). Goodall stated in this interview that: "It certainly appeared at times that he [Harambe] was being gentle, but he was nervous and agitated by the unexpected arrival of the child and the shouting of the people watching." In saying this, Goodall drew attention to the crowd stimulus and the novelty affects on the Gorilla's behavior and thus to the very limits of species-driven, behavioral analysis in this particular circumstance. Goodall points directly to interspecies interactional affects and effects which can be better appreciated by bracketing the distinction Heidegger (1995) made between animal "behavior" and human "comportment" (p. 237) and by explicating moment-to-moment what Sheets-Johnstone refers to as "synergies of meaningful moment" (Sheets-Johnstone, 2016, p. 1, emphasis in original).

We see in the video posted on-line how the three-year-old child who fell into the water within the Gorilla compound is held close, as well as at arm's length, by a "livingly resonant tactile-kinesthetic body" (Sheets-Johnstone, 2016, p. 7) that is affected by the spectators' cries and frenetic motions. The child affects and effects a responsiveness as well. He is shielded for a while from these cries of human distress by the bulky barrier of the Gorilla's body, although now in evident emotional distress himself there is a contagion of feeling, a rushing, upwelling force of suffering, from which Harambe appears to want to escape. In a burst of speed, Harambe drags the seated child by the leg through the shallow water, moving well away from the corner of the compound where he likely felt trapped, or at least set upon. Now somewhat out in the open, a tenderness appears in the gorilla's motions. The child is helped to his feet, straightened up, and turned around with a lightness of touch that belies the gorilla's strength. One can imagine a young gorilla in this situation leaning into the Silverback and clinging to his fur just as a human child might fall into a parental embrace. A calming of the young one's fright would likely occur in the closeness and warmth of bodily contact. But the child's cries and the cacophony of human calls from above appear again to provoke the gorilla into flight as he drags the young boy farther away until both adult gorilla and human child are fully out of sight.

Where kinesthesia and affectivity start and end is impossible to discern in this scenario, especially when all we have is the visual kinetic evidence. But where Sheets-Johnstone (2016) claims that movement in its "spontaneity is the most elementary form of agency" (p. 6), I will concur and yet press the case for "synergies of meaningful movement" (p. 1) and, especially, synergies of movement for which we have yet to discern agentic meaning as the most 
elementary, tactile-kinesthetic, and affective motivations. Accordingly, I am not convinced that the "resonant tactile-kinesthetic body" attests fundamentally to an "I move" (p. 7), but rather that this bodily capability attests fundamentally to a $W e$ move. Even in captivity, even with the putative and potent powers of animal agency creating so much trepidation and concern, Harambe's interaction with the young boy in the Gorilla compound at the Cincinati Zoo gave the world glimpses of a tactile-kinesthetic and affective We-ness. ${ }^{7}$ How might we better appreciate the movement potentiality and possibilities of this hetero-affectivity?

\section{In the Zone of Hetero-Affectivity}

The third illustration, of human-horse interaction, is suggestive of practices of not so much capturing as potentially rapturing in the intercorporeal, interspecies dynamics of motional attunement. Here I intuit with Michel Henry's help the possibilities of realizing motional mimesis at a deeply tactile, kinesthetic, affective and, consequently, kinethic level of practical commitment (Smith, 2014b).

I think of Twilight, the eight-year-old Chincoteague mare who presents herself initially to me as a pampered and rude creature. She kicks and bites those who approach her, including Valentino, the big lunky Friesian gelding from whom she has taken a few chunks of flesh and who retains the scars of these altercations. Twilight runs riot among the miniature horses such that little Joey and Lily can be seen cowering in the paddock corners or looking for refuge in the gardens when Twilight is on the rampage. Still, over the months of working with Twilight on the ground and in the saddle and observing her interactions with the other horses and farm animals, I have come to appreciate the life that Twilight expresses and the means of attuning to her life force. This spirited, jet-black mare shows an independent, assertive demeanor that must have served her feral forebears well on Assateague Island. Yet this same horse grieved for days in the spot where her former stable mate, Emily the rescued racehorse, lies buried.

I halter Twilight out in the field and lead her through a gate into the outdoor riding arena where I turn her loose. She wants little to do with me and proceeds to run to the corner of the arena from where she can still see Valentino. I wait in stillness until she stops whinnying and then step toward her hind end, motioning for her to move out of this corner and in the direction I am pointing with my extended arm. I 'press' more energetically on her hindquarters until Twilight responds in a lively, cadenced trot around the perimeter of the arena. She breaks into a canter that builds quickly into a flat-out gallop. She appears full of herself, which is to say, full of her movement powers. I close the gap a little between Twilight and me and then, shifting my attention momentarily to her shoulder region, 'press' against the momentum barreling her forward. Twilight shifts her weight over her back end and gears down through the canter to a collected trot. I press once more on her hindquarters, as if 'pushing' them sideways and outwards, but before Twilight can again turn this 'push' into an increased tempo in her gait, I withdraw backwards to the center of the arena. Twilight 'draws' toward me. She bends her body away from the arena perimeter and follows an arcing radius to me. But, before there is any

\footnotetext{
${ }^{7}$ Particularly telling visuals of tactile-kinesthetic-affective connections with captive Lions (and Hyenas) can be viewed in documentaries of Kevin Richardson's animal conservancy work in South Africa. See, for example, Richardson (2015). Similar visuals can be found in cases of captive and released-to-the-wild gorillas (e.g. Aspinall Foundation, 2015).
} 
danger of her running through me, I signal a new direction for her with my opposite arm now extended while 'pressing' the newly open side of her body away from me and then directing my attention to her hind end for her to again step under herself in collected, forward impulsion.

We continue in this way, circling to the right, and to the left, while turning these changes of direction progressively into flowing figures-of-eight. We play with the kinetic dynamics of pushing and drawing and with the kinesthetics of breathing, balancing, timing and feeling. We find an attunement with one another in motional mimesis and in the nuanced, moment-tomoment feelings for one another that register as upwellings, upsurges, rushes, gushes, bursts and flushes, as well as in the fadings, ebbings, flattenings and settlings of synergistic exchange. Twilight becomes the horse with whom I can once again experience in motion, within the initial commotions and through the mimic interplay of liberty training, a vital connection with another animate being. I finish the session with Twilight 'on my shoulder,' following side-by-side my own gaits from a walk to a lope, to a run, back to a trot, forwards, backwards, and sideways, stopping, starting again, although it is not fully clear if Twilight is following me or I am following her.

With Twilight, I am playing with Henryean notions of the auto-affectivity of life flowing into the hetero-affectivity of moods, emotions and conjoint feelings of vitality. I regard Equestrian Arts in these very practical terms. Such arts extend from Ground Work to Liberty Training and to the classical riding discipline of Dressage (Smith, 2014a, 2015b) where the commonality lies in partnered practices based on postural, positional, gestural and expressive communication. The actual performances may be spontaneous or tightly choreographed, but the moment-to-moment interactions cannot be fully anticipated or preplanned. The essential interaction is a fluid responsiveness to miniscule pressures and undulations in the simplest, most subtle of contacts. These mimetic movements have, moreover, a durational, relational quality (Stern, 2004, 2010), lending affectivity to the biomechanics and techniques of what may look simply like an action-reaction, lead-and-follow relationship (Smith, 2010, 2014a). Egoic agency gives way to interactive affectivity.

A key phrase characterizing equestrian arts is that of bringing up life, which is indicative of the "vitality affects" that operate kinesthetically in response to and as influencing the kinesis of the horse (Smith, 2010, p 19). This phrase points to the auto-affectivity of life, which Michel Henry $(2008,2015)$ takes to the transcendental extreme, as the noetic aspect of an essential hetero-affectivity. Bringing up life is the actional-reactional, energetic interplay of an immanent auto-affectivity that infuses a life lived motionally with others (cf. Seyler, 2012). Working with, training, playing with, or just hanging out with horses, in spite of all the constraints, reveals bringing up life to be like whiffs, feelings, touches and fleeting contacts with and within a wider, wilder sense of being with others. This rippling out of life's auto-affectivity into the living presentness of hetero-affectivity is elementally like ripples and waves that co-respond to currents and flows of air, and with grains and textures of earth and materials, and with flames and tongues of fire (cf. Smith, 2016; 2017b, in press).

Now, I confess that my take-up of Henryean life phenomenology remains uncertain. Aside from my reservations about his onto-theological commitments (Henry, 2003, 2012b), I find his reinstated dualism of the immanent, auto-affectivity and auto-donation of life in direct opposition to ecstatic, worldly manifestations of life that turn so easily to forms of "barbarism" (Henry, 2012a) to be seemingly counter-intuitive to what I experience and have come to understand about vital, life-enhancing, life-affirming contact and connection with others. By the same token, it is the suggestiveness of Michel Henry's writings that is helpful in getting at the 
affectivity of interspecies relations. So, while Henry very rarely mentioned animals, and while his material phenomenology almost seems antithetical to the praxis of humanimality, his work continues to beg the question of how a revelatory auto-affection can be a "pathos-with" others and the gift of hetero-affection (Henry, 2008, pp. 101-134; cf. Gély, 2012).

Henry's life phenomenology seems to me a resource for feeling our ways through the ontological divides, chasms, abysses, gaps, fissures and chiasmas that otherwise foreclose the possibilities of connection across putative species boundaries. Joseph Rivera's (2015) text on The contemplative self after Michel Henry provides some keen insights in this regard, especially in his treatment of such Henryean passages as:

For in the irruption of life and in its wave, which moves in us and renders us both full with it and ourselves, there is not a gap, nor any distance or any possibility of a response, of a yes, or a no (p. 126).

It seems to me that although Henry essentialized life too much, he, like Heidegger in his Trakl essay, could not help using the terminology of "vitality affects" (of upsurges, waves, fadings, etc.) and thus of calling attention to the phenomenality of animation and of moving in concert with others.

I can't help but feel kinesthetically, and through breathing, balancing, timing and resonant 'touches,' that in my most playful interactions with my horses, whether riding or in liberty training, I can get inside the (other) animal's skin and move in ways such that life flows interactively and animatingly through us (Smith, 2011, 2014a, 2014b, 2015a, 2015b). Certainly we can become more disposed to "fluid moving in concert" with others (Sheets-Johnstone, 2006, p. 264) through many individual physical arts and somatic disciplines even where the milieu of action is, at best, regarded as background effect. But as we come to better appreciate motility as animation and became more immersed in environmental and nature pursuits, this sense of animation shifts to the spaces, times and experiences of transposition, translation, and what Ralph Acampora (2006) terms "transpecific conviviality" in his book on Animal Compassion and what David Abram (2010) explores animistically in his two books and especially the second one on Becoming Animal. ${ }^{8}$

\footnotetext{
${ }^{8}$ Heidegger (1995) makes the point that Dasein is fundamentally "being with" others, as "being transposed into other human beings," since "the being-there of Dasein means being with others, precisely in the manner of Dasein, i.e., existing with others" (p. 205). Bracketing Heidegger's ontological humanism, and the "being with" that distinguishes human beings, we can come to better appreciate how transpositions between humans and other animate beings are vitally affected. In fact, we can come to appreciate how the assumption of animal world-poorness is rooted in us being held captive to cultivated human movements (repertoires of I cans) that refuse to go along with other animals' motions (I can 'ts). Heidegger reminds us that "potentiality and possibility belong precisely to the essence of the animal" and "[o]nly something that is capable, and remains capable, is alive" (p. 235-236).
} 


\section{Conclusion}

"Languaging the inherent dynamics of life" is the challenge to which Sheets-Johnstone responded in her 2016 IHSRC keynote address. It is "the phenomenological challenge" of describing "the foundational significance of movement" (Sheets-Johnstone, 2016). Responding to this challenge specifically in the context of humanimality means divining conceptual, linguistic and even prelinguistic means of finding our ways back to living convivially, harmoniously and responsibly alongside the creatures from whom we have distanced ourselves in our Heideggerian "world-forming" pretensions. How we take up this "phenomenological challenge" is the question we each need to answer in ways such that our phenomenologies can be life-affirming and life-enhancing for ourselves and others. A focus on the vitality of humanimality can thus be regarded as a particularly poignant way of posing "the phenomenological challenge" of describing "the foundational significance of movement" in being with others of our own and other kinds.

The claim I make for the vital significance of moving in concert with others of an another animal kind has drawn upon Sheets-Johnstone's work, along with Heidegger's and Henry's writings, as particularly valuable for not just somatically agentic, but also motivationally ethical consideration of interspecies relations. By using illustrative scenarios involving various animals of an admittedly higher mammalian kind as the points of departure for phenomenological analysis, the vitality of humanimality has been cast as appreciation of, responsiveness to and intrinsic connectedness with these other beings. And yet there can be no definitive moral conclusions reached as to the right and best courses of action to take on behalf of these creatures. If the 'canned' trophy hunting of African Lions is exposed as barbarity, and keeping Western Lowland Gorillas in captivity can only be justified as a conservation tactic in the face of devastating loss of natural habitat, the domestication, training and riding of horses can likewise be critiqued for its continuing exercise of human powers over creaturely ways. The problem with this conclusion, however, is that such ethical considerations still seem laden with the very anthropocentric values they seek to critique.

Matthew Calarco (2008) poses the question: "Might not the challenge for philosophical thought today be to proceed altogether without the guardrails of the human-animal distinction and to invent new concepts and new practices along different paths?" (p. 149). The pathway indicated in the present exploration of the vitality of humanimality may well be suggestive of "new concepts and new practices," however we ought not forget the starting point, and the need for an ongoing return to the things themselves, that was initially suggested in the question of motivation posed in the earlier part of this paper. Rather than inventing "new practices," we might continue to interrogate practices of human exceptionalism through the phenomenological resources available to us while being reminded of those practices of human-animal connection that are motivationally already at hand.

My initial childhood intuition of such practices has been traced from Heideggerian ontology to Henryean life phenomenology and tracked through the movement-focused analyses of Sheets-Johnstone. The intuition is captured well by Henry (2015) in stating that "the bodies of the universe are given originally only to the immanent powers of our corporeity" (p. 149). Other organic bodies, other creatures, can be perceived as separate from us, and we human beings from them, only by an intentionality that denies the immanence of life awareness, its auto-affectivity and thus its auto-revelation in manifold life forms and modes of life encounter. At the heart of the intuition, which I addressed at the outset of this paper, is “the 'I can' of our original 
corporeity" (p. 150). This "I can" is even more originary than the "moving-moving" (SheetsJohnstone, 2009, p. 259) of a life lived alongside others. It is, following the reversal of phenomenology that Henry pursued and the impressional affectivity that the interrogation of humanimality has disclosed, an invisible power to move in concert with others in ways limited only by the resistances that constitute the very meaning of the "I can." The movements of animate consciousness well up from the auto-affectivity of life's self generation and appear in motions of hetero-affection by the very manner of appearing that is given in motional resonances across interspecies lines. And this "incandescent," "burning," "shining flesh," as Henry (2015) termed it, appears somehow of a kind with the pulsing, luminescent iridescence of those little blue-ringed octopuses.

In casting off animal assumptions and reclaiming our animate affinities, we may not only relearn what it means to move in concert with other animal beings, but also how to revitalize the relational contiguities, correspondences and affinities that can exist amongst ourselves. This revitalization was suggested some decades ago by Max van Manen (1991) in a piece of writing that may well have been a harbinger of the present undertaking. Titling the piece "the vitality of the pedagogical relation," van Manen wrote specifically about the nature of those relationships created between adults and children that are "animated by a special quality that spontaneously emerges between adult and child and that can be neither managed or trained, nor reduced to any other human interaction" (p. 178). The pedagogical relationship is defined essentially by a certain "human vitality that captures the normative and qualitative features" of the "communities of informal life" cultivated in the actions, interactions and practices of adult responsiveness to the children and youth in our care (van Manen, 2016, p. 89). It is a cultivated relationship of empathic, animated responsiveness (Smith, 1998). "Less a way of being unto oneself, and more a sense of becoming otherwise, attuned to others' motions and correlative emotions, pedagogical relationality can be formed and deeply informed by practices and disciplines of corporeal responsivity" (Smith, 2014b, p. 243). I embellish such statements further by saying that pedagogical relationality and its practices and disciplines of corporeal responsivity and responseability need to extend beyond our human-to-human modes of responsiveness and to fuller appreciation of other animal beings who have us realize the intrinsically animated and inherently vital connectedness we have with them within the unfolding, enfolding movements of life itself.

\section{References}

Abram, D. (2010). Becoming animal: An earthly cosmology. New York: Pantheon Books.

Acampora, R. A. (2006). Corporal compassion: Animal ethics and philosophy of the body. Pittsburgh: University of Pittsburgh Press.

Agamben, G. (2002). The open: Man and animal (K. Attell, Trans.). Stanford, CA: Stanford University Press. (Original work published 2000)

Aspinall Foundation. (2015). A gorilla remembers a girl it had not seen for 12 years, Youtube video: https://www.youtube.com/watch?v=Xarwk2d5Jm8

Cajete, G. (1994). Look to the mountain: An ecology of indigenous education. Durango, CO: Kivaki Press. 
Calarco, M. (2008). Zoographies: The question of the animal from Heidegger to Derrida. New York: Columbia University Press.

Cimatti, F. (2016). Beyond the human/non-human dichotomy: the philosophical problem of human animality, Humanimalia, 7(2), 35-55.

Derrida, J. (2004). The animal that therefore I am (More to follow). In P. Atterton \& M. Calarco (Eds.), Animal philosophy: Essential readings in continental thought (pp. 113-128). New York: Continuum.

Derrida, J. (2008). The animal that therefore I am (D. Willis, Trans.). New York: Fordham University Press. (Original work published 2006)

Downes, A. (2016). Jane Goodall, Assedine Downes together offer thoughts on tragic Harambe killing, International Fund for Animal welfare, http://www.ifaw.org/unitedstates/news/jane-goodall-azzedine-downes-together-offer-thoughts-tragic-harambekilling

Eldon, S. (2006). Heidegger's animals, Continential Philosophy Review, 39, 279-291.

DOI: $10.1007 / \mathrm{s} 11007-006-9020-7$.

Gély, R. (2012). Towards a radical phenomenology of social life: Reflections from the work of Michel Henry. In J. Hanson \& M.R. Kelly (Eds.). Michel Henry: The affects of thought (pp. 154-177 ).London: Bloomsbury.

Heidegger, M. (1971). On the way to language. (D. Hertz, Trans.). New York: Harper and Row. (Original work published 1959)

Heidegger, M. (1995). The fundamental concepts of metaphysics: World, finitude, solitude. (W. McNeill \& N. Walker, Trans.). Bloomington, IN: Indiana University Press. (Original work published 1983)

Heidegger, M. (2016). Ponderings I-VI: Black notebooks, 1931-1938. (R. Rojcewicz, Trans.). Bloomington, IN: Indiana University Press. (Original work published 2014)

Henry, M. (2003). I am the truth: Toward a philosophy of Christianity. (S. Emanuel, Trans.). Stanford, CA: Stanford University Press. (Original work published 1996)

Henry, M. (2008). Material phenomenology. (S. Davidson, Trans.). New York: Fordham University Press. (Original work published 1990)

Henry, M. (2009) Seeing the invisible: On Kandinsky. (S. Davidson, Trans.). New York: Continuum. (Original work published 1988)

Henry, M. (2012a) Barbarism. (S. Davidson, Trans.). New York: Continuum. (Original work published 1987) 
Henry, M. (2012b). Words of Christ. (C.M. Gschwandtner, Trans.). Grand Rapids, MI: William B. Herdsmann. (Original work published 2002)

Henry, M. (2015). Incarnation: A philosophy of flesh. (K. Hefty, Trans.). Evanston, Ill: Northwestern University Press. (Original work published 2000)

Ingold, T. (2000). The perception of the environment: Essays on livelihood, dwelling and skill. New York: Routledge.

Kleinberg-Levin, D. M. (2005). Gestures of ethical life: Reading Hölderlin's question of measure after Heidegger. Stanford: Stanford University Press.

Mitchell, A. J. (2011). Heidegger's later thinking of animality: The end of world poverty. Gatherings: The Heidegger Circle Annual, 1, 74-85.

Oma, K.A. (2010). Between trust and domination: Social contracts between humans and animals. World Archeology, 42 (2), 175-187.

Richardson, K. (2015). Amazing lion ranger Kevin Richardson. https://www.youtube.com/watch?v=4HqepFm60cM

Rivera, J. (2015). The contemplative self after Michel Henry: A phenomenological theology. Notre Dame, Indiana: University of Notre Dame Press.

Seyler, F. (2012). From life to existence: A reconsideration of the question of intentionality in Michel Henry's ethics. Journal of French and Francophone Philosophy, 20 (2), 98-115.

Sheets-Johnstone, M. (2006). Essential clarifications of 'self-affection' and Husserl's 'sphere of ownness': First steps toward a pure phenomenology of (human) nature. Continental Philosophy Review, 39: 361-391. DOI: 10.1007/s11007-006-9039-9

Sheets-Johnstone, M. (2008). The roots of morality. University Park, Pennsylvania: The Pennsylvania State University Press.

Sheets-Johnstone, M. (2009). The corporeal turn: An interdisciplinary reader. Exeter, UK: Imprint Academic.

Sheets-Johnstone, M. (1999/2011). The primacy of movement $\left(1^{\text {st }}\right.$ and $2^{\text {nd }}$ ed.). Amsterdam: John Benjamins.

Sheets-Johnstone, M. (2013). Movement as a way of knowing, Scholarpedia: The peer-reviewed open-access encyclopedia. doi:10.4249/scholarpedia.30375 
Sheets-Johnstone, M. (2014). Animation: Analyses, Elaborations, and Implications. Husserl Studies, 30: 247-268. DOI 10.1007/s10743-014-9156-y

Sheets-Johnstone, M. (2016). Agency: Husserl's phenomenological insights and dynamic complementarities. Keynote Address presented at the $35^{\text {th }}$ International Human Science Research Conference, University of Ottawa, July 3-7.

Smith, S. J. (1992). Physically remembering childhood. Phenomenology + Pedagogy, 10, 85106.

Smith, S. J. (1998). Risk and our Pedagogical Relation to Children. Albany, NY: State University of New York Press.

Smith, S. J. (2007). The first rush of movement: A phenomenological preface to movement education. Phenomenology \& Practice, 1 (1), 47-75.

Smith, S. J. (2011). Becoming horse in the duration of the moment. Phenomenology \& Practice, $5(1), 7-26$.

Smith, S. J. (2013). Caring caresses and the embodiment of good teaching. Phenomenology \& Practice, 6(2), 65-83.

Smith, S. J. (2014a). Human-horse partnerships: The discipline of dressage, in Sport, animals, and society (J. Gillett and M. Gilbert, Eds.). New York: Routledge, 35-51.

Smith, S. J. (2014b). A pedagogy of vital contact. Journal of Dance and Somatic Practices, 6 (2), 233-246.

Smith, S. J. (2015a). Riding in the skin of the moment: An agogic practice. Phenomenology \& Practice, 9 (1), 41-54.

Smith, S. J. (2015b). Dancing with horses: The science and artistry of coenesthetic connection. In N. Carr (Eds.), Domestic animals and leisure. (p. 296-326). London: Palgrave MacMillan,

Smith, S. J. (2016). Movement and Place. In M. Peters (Eds.), Encyclopedia of Educational Theory and Philosophy. New York: Springer, doi:10.1007/978-981-287-532-7_92-1.

Smith, S. J. (2017a, in press). Being with horses as a practice of the self-with-others: A case of getting a FEEL for teaching. In O. Gunnlaugson, E. Sarath, H. Bai, \& C. Scott (Eds.), The Intersubjective Turn in Contemplative Education: Shared Approaches for Contemplative Learning and Inquiry Across the Disciplines. New York: SUNY Press.

Smith, S. J. (2017b in press). Flow motion and kinethic responsiveness. In I.L. Stefanovic, A. Wellington, \& S. Young (Eds.), Water Ethics and Environmental Policy. Toronto: University of Toronto Press. 
Stern, D.N. (1993). The role of feelings for an interpersonal self. In Neisser, U. (Eds.), The perceived self: Ecological and interpersonal sources of self knowledge (205-215). Cambridge: Cambridge University Press.

Stern, D. N. (2002). The first relationship: Infant and mother. Cambridge, MA: Harvard University Press.

Stern, D. N. (2004). The present moment in psychotherapy and everyday life. New York: W.W. Norton \& Company Inc.

Stern, D.N. (2010). Forms of vitality: Exploring dynamic experience in psychology, the arts, psychotherapy, and development. Oxford: Oxford University Press.

Toadvine, T. (2007). How Not to Be a Jellyfish: Human Exceptionalism and the Ontology of Reflection. In C. Lotz \& C. Painter (Eds.), Phenomenology and the Non-Human Animal: At the Limits of Experience (39-55). Berlin: Springer.

Tyler, T. (2005). Like water in water, Journal for Cultural Research, 9 (3), 265-279.

van Manen, M. (1992). The vitality of the pedagogical relation. In B. Levering, S. Miedema, S. Smith \& M. van Manen (Eds.), Reflections on pedagogy and method (173-192). Montfort: Uriah Heep.

van Manen, M. (2016). Pedagogical tact: Knowing what to do when you don't know what to do. New York: Routledge.

Von Uexküll, J. (2010). A foray into the worlds of animals and humans (J.D. O'Neil, Trans.). Minneapolis: University of Minnesota Press.

Wittgenstein L. (1953). Philosophical Investigations. New York; Prentice-Hall. 